\title{
Association between 25-hydroxyvitamin D levels and Diabetes
}

\author{
G. Papadakis ${ }^{1}$, K. Kakava ${ }^{2}$, T.Pappa ${ }^{1}$, N. Dogkas ${ }^{3}$, V.Villiotou ${ }^{3}$, A. Pappas ${ }^{1}$ \\ DepartmentofEndocrinology ${ }^{1}$, Otolaryngology ${ }^{2}$ and Biochemistry ${ }^{3}$ \\ MetaxaAnticancer Hospital,Athens Pireaus, GREECE
}

- Introduction: A significant body of literature supports that $25(\mathrm{OH})$ vitD deficiency is associated with insulin resistance. We studied the prevalence of $25(\mathrm{OH})$ vitD deficiency across the spectrum of glucose metabolism.

- Design: The study participants (441 total, 362 females (82.1\%) and 79 males $(17.9 \%))$ had a mean age $( \pm S D)$ of $64.59( \pm 9.44)$ years, range: 32 - 92 years. The study population was divided into 2 groups: Individuals with Diabetes $(n=184,33$ males), and controls with normal glucose levels ( $n=257,46$ males).

- Results: The mean 25(OH)vitD values for

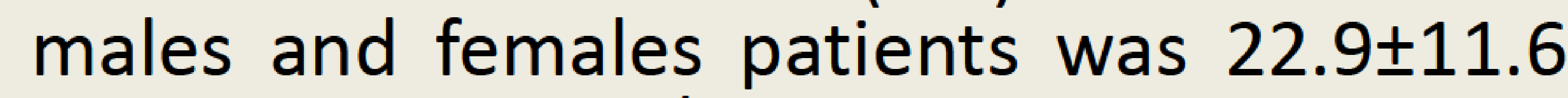
and $21.6 \pm 11.9 \mathrm{ng} / \mathrm{mL}$ respectively, $\mathrm{p}=0.815$. The mean $25(\mathrm{OH})$ vitD \pm SD levels were significantly lower in subjects with diabetes $(18.6 \pm 10.6 \mathrm{ng} / \mathrm{mL})$ compared to normal subjects $(24.2 \pm 12.2 \mathrm{ng} / \mathrm{mL}), p=0.035$. There was no difference in the mean age of patients and sex distribution between the two groups. $25(\mathrm{OH})$ vitD deficiency was observed in $49.7 \%$ of the entire study population and was significantly more frequent in patients with diabetes compared to controls $(60.9$ vs $41.6 \%$ respectively). Only 26 out of $184(14.1 \%)$ of patients with diabetes had $25(\mathrm{OH})$ vitD sufficiency and levels above $30 \mathrm{ng} / \mathrm{ml}$, compared to 74 out $257(28.8 \%)$ of individuals with normal glucose $(p<0.001)$.

- Conclusions: This study illustrates the higher prevalence of $25(\mathrm{OH})$ vitD deficiency among patients with diabetes. From a clinical standpoint, specific advice needs to be provided especially to people with diabetes. Vitamin $D$ supplements on a regular basis over the year and adequate sun exposure could be also recommended in order to achieve sufficient levels of $25(\mathrm{OH})$ vitD.
Table 1. Mean values \pm SD of $25(\mathrm{OH})$ vitD, age, plasma glucose levels and $\mathrm{HbA} 1 \mathrm{c}$ in the two groups of patients.

\begin{tabular}{|c|c|c|c|c|c|}
\hline & $\begin{array}{l}\text { Male } \\
\text { (N/\%) }\end{array}$ & $\begin{array}{c}\text { Age in } \\
\text { years }\end{array}$ & $\begin{array}{r}25(\mathrm{OH}) \mathrm{vitD} \\
(\mathrm{ng} / \mathrm{ml})\end{array}$ & $\mid \begin{array}{r}\text { Glu } \\
(\mathrm{mg} / \mathrm{dl})\end{array}$ & $\begin{array}{r}\text { HbA1c } \\
(\%)\end{array}$ \\
\hline & & $\begin{array}{l}\text { Mean } \\
( \pm S D)\end{array}$ & $\begin{array}{l}\text { Mean } \\
( \pm \mathrm{SD})\end{array}$ & $\begin{array}{l}\text { Mean } \\
( \pm S D)\end{array}$ & $\begin{array}{l}\text { Mean } \\
( \pm \mathrm{SD})\end{array}$ \\
\hline Diabetes & 33 & 64.48 & 18.6 & 165.9 & 7.81 \\
\hline$n=184$ & $/ 17.9 \%$ & $( \pm 10.83)$ & $( \pm 10.6)$ & $( \pm 60)$ & $( \pm 1.35)$ \\
\hline Normal & $46 /$ & 64.66 & 24.2 & 91.2 & 5.38 \\
\hline$n=257$ & $17.9 \%$ & $( \pm 8.32)$ & $( \pm 12.2)$ & $( \pm 8.6)$ & $( \pm 0.2)$ \\
\hline p-values & & & $P=0.035$ & $P<0.00$ & $P<0.001$ \\
\hline
\end{tabular}

1

Table 2. Counts and percentages of subjects with $25(\mathrm{OH})$ vitD deficiency $(<20 \mathrm{ng} / \mathrm{ml})$, insufficiency $(20-<30 \mathrm{ng} / \mathrm{ml})$ and sufficiency $(\geq 30 \mathrm{ng} / \mathrm{ml})$ in each group of patients

\begin{tabular}{|l|l|l|l|}
\hline & $\begin{array}{l}\text { vitD } \\
\text { deficiency }\end{array}$ & $\begin{array}{l}\text { vitD } \\
\text { insufficiency }\end{array}$ & $\begin{array}{l}\text { vitD } \\
\text { Sufficiency }\end{array}$ \\
\hline Patients with DM $(n=184)$ & $112(60.9 \%)$ & $46(25 \%)$ & $26(14.1 \%)$ \\
\hline $\begin{array}{l}\text { Patients without DM } \\
(n=257)\end{array}$ & $107(41.6 \%)$ & $76(29.6 \%)$ & $74(28.8 \%)$ \\
\hline
\end{tabular}

References

1) Song Y, Wang L, Pittas AG, Del Gobbo LC, Zhang C, Manson JE and Hu FB: Blood 25-hydroxy vitamin D levels and incident type 2 diabetes: a meta-analysis of prospective studies. Diabetes Care 36(5): 1422-1428, 2013. 2) Pittas AG, Nelson J, Mitri J, Hillmann W, Garganta C, Nathan DM, Hu FB and Dawson-Hughes B: Plasma 25hydroxyvitamin $D$ and progression to diabetes in patients at risk for diabetes: an ancillary analysis in the Diabetes Prevention Program. Diabetes Care 35(3): 565-573, 2012.

3) Mitri J, Dawson-Hughes B, Hu FB and Pittas AG: Effects of vitamin D and calcium supplementation on pancreatic beta cell function, insulin sensitivity, and glycemia in adults at high risk of diabetes: the Calcium and Vitamin D for Diabetes Mellitus (CaDDM) randomized controlled trial. Am J Clin Nutr 94(2): 486-494, 2011. 4) Mathieu C, Gysemans C, Giulietti A and Bouillon R: Vitamin D and diabetes. Diabetologia 48(7): 1247-1257, 2005

5) Takiishi T, Gysemans C, Bouillon R and Mathieu C: Vitamin D and diabetes. Rheum Dis Clin North Am 38(1): 179-206, 2012

6) Shankar A, Sabanayagam C and Kalidindi S: Serum 25-hydroxyvitamin d levels and prediabetes among subjects free of diabetes. Diabetes Care 34(5): 1114-1119, 2011. 